\title{
Izabela Bartkowicz
}

\section{MIĘDZY HISTORIĄ A BIBLIA - \\ $O$ „LEGIONIE" S. WYSPIAŃSKIEGO}

\author{
HISTORIA I BIBLIA
}

Konkretna jednostka wpisana w czas historii - Adam Mickiewicz obok znajdującego swoje miejsce zarówno w historii świata, jak i człowieka - Chrystusa.

Wymarzona Polska - owo źródło marzeń romantyków, które wiek XIX tak bardzo ożywił nadzieją na Niepodległą i Jeruzalem Niebieskie - ów lśniący blaskiem szlachetnych kamieni cel drogi każdego chrześcijanina.

Czy możemy dokonywać takich paraleli?

Czy możemy stawiać obok siebie tak różne rzeczywistości? czem.

„Legion” Wyspiańskiego pozwala otwierać się właśnie tym klu-

Uczyńmy punktem wyjścia naszych rozważań rozjaśnienie znaczenia terminu. Wyraz „legion” bardzo wyraźnie wpisuje się w zakres słownictwa militarnego. Słownikowa definicja precyzuje: „jednostka wojska rzymskiego licząca teoretycznie sześć tysięcy ludzi (w praktyce zawsze mniej)" i nieco dalej: „ochotnicza formacja wojskowa”. ${ }^{1}$

Dramat Wyspiańskiego, bardzo wyraźnie osadzony w rzeczywistości historycznej XIX-wiecznej Polski (wydarzenia zamknięte latami 1844-1846) uczyni przedmiotem swoich odwołań z jednej strony Legiony Dąbrowskiego - pierwszy niezwykle istotny krok na drodze odzyskiwania utraconej niepodległości. O nich, w słowach pełnych goryczy opowiada Rapsod - świadek klęsk Polaków, ten, który „wraca z narodu mogiły". Co pozostało po wielkim czynie?

Serce zbrzydło, miłość zbrzydła, ciało skłute, serce strute, ot, i połamane skrzydła.

Ożarły się syto sępy, miłość strzępy, serce strzępy. ${ }^{2}$

1 W. Kopaliński, Stownik wyrazów obcych $i$ zwrotów obcojęzycznych $z$ almanachem, Warszawa 1994, s. 296.

2 Ten i następne cytaty pochodzą z: S. W y s piański, Legion, Kraków 1989, sc. IX, ww. 267-271. 
Jaka chwała spotyka dzisiaj wczorajszych bohaterów?

(...) jem chleb łzawy,

chleb żebraczy,

Bóg mnie raczy (...)

Ot, na piersi mojej znaczą

rabaty, żem był przy legionie,

a w sercu, a w piersiach płaczą

żale i skargi, i klęcia;

więc ja moje żale dzwonię (...)

(sc. IX, ww. 279-281, 288-291)

I jeśli zapytać: dlaczego? - odpowiedź podobnie jak pytanie nie będzie precyzyjna, ale wystarczająca:

Byliśmy radośni na stan,

byliśmy młodzi

i nie liczyli ran,

radośni na to krwi znamię.

(sc. IX, ww. 307-310)

W niegdyś młodych, rozpalonych czynem pozostało jednak coś bardzo istotnego - wiara. Głos starca staje się głosem całego narodu antycypując wydarzenia:

Kiedyś godzinę wołaną

będziemy, będziemy mieć

Powstaną nad nami, powstaną,

w powietrzu będą drżeć

chorągwie - to będzie wczas rano.

(sc. IX, ww. 320-324)

Obok spiętych już klamrą przeszłości Legionów, Wyspiański dotyka problemu innego - legionu formowanego w Rzymie przez autora III cz. Dziadów - Legionu Mickiewicza (28 marca 1846 - zawiązanie oddziału polskiego). To znowu wielka i piękna polska idea, która ukonkretniona w działaniu, stała się mało istotnym epizodem w dochodzeniu do Niepodległej. Posłuchajmy głównego bohatera - Mickiewicza - jego interpretacja legionowej formacji, legionowej aktywności pozwala wejść w głęboko romantyczną (irracjonalną) atmosferę owych czasów. Poeta rozszerza rozumienie pojęcia "legion" do narodu - chciałby ujrzeć w zbrojnej gotowości wszystkich Polaków, nieprzypadkowo więc dodaje epitet „zwycięski”. Jaką wyznacza sobie rolę? Dokładnie taką, jak określono to w „akcie zawiązania" zastępu polskiego: „zebrani rodacy (...) obierają namiestnikiem swoim i dotychczasowym przewodnikiem Adama Mickiewicza".3 Jak widzi jej praktyczną realizację?

8 Cyt. za: J. Nowakowski, Wstęp, w: S. W ys piański, j.w., s. XXVII-XXVIII. 
Przysięgam za Polskę, klnę święcie:

przechować dusz wniebowzięcie,

niepokalanie żyć w Bogu, mój naród u Niebios progu

ostawić: legion zwycięski.

(sc. VII, ww. 335-339)

W innym miejscu zdaje się ukonkretniać cel działań oddziału, a raczej wciąż jeszcze narodu, mówiąc:

Duch chce was mieć żołnierze, (...)

słuchajcie, słyszycie legiony:

pójdziemy, pójdziemy daleko;

wskrzeszać, obalać trony (...)

trony obalim $\mathrm{w}$ nicestwo,

wyzwolim Królestwo Ducha.

(sc. IX, ww. 75, 77-79, 82-83)

Czy tak gorliwa deklaracja odpowiada rzeszom pragnącym realnej, dotykalnej realizacji wielkiego zamierzenia przywrócenia Polsce niepodległości - „przez krew”? Mickiewicz rozpaczliwie próbuje powstrzymać tłum:

(...) nie patrzcie, nie patrzcie na krew (...)

weźmijcie, weźmijcie na czoła

zwycięstwo, zwycięstwo Ducha, pokoju wieczyste znamię.

(sc. IX, ww. 129, 132-134)

Nic jednak nie zdoła odwrócić już jego wielkiej tragedii - dramatu przewodnika wiodącego naród. Bo i on nie dość dobrze go zrozumiał, a i rzesza - pojąć nie mogła wielkich słów swojego dowódcy. Pozostając sam (jak dalece boleśnie ironiczny i jak prawdziwy jest Wyspiański nakładając mu w tym momencie „kostium” poety uwieńczonego laurem) pośród porzuconych, zdruzgotanych, wdeptanych z nienawiścią i świadomością oszukania, sztandarów, przez łzy zdoła jeszcze krzyknąć swojemu umierającemu legionowi:

\author{
Przekleństwo, przekleństwo Ducha! \\ Szatany jawią złe moce, \\ padły strącone sztandary. \\ Legionie, legionie wiary!! \\ Podeptali chorągwie i godła: \\ obłędów okrutna męko - \\ aż tu je chorągiew przywiodła \\ i tu własną zabili ją ręką. \\ Legionie, o święte godła! (...)
}


o męko, serdeczna męko, legionie, legionie wiary.

(sc. IX, ww. 133-191, 193-194)

„Legion” - tak jak pojmuje go Mickiewicz - odbiega od interpretacji czysto militarnej. To nie jedynie oddział, ale głęboko czujący swoje nieszczęście ludzie - Polacy. To naród, naród zwycięski, który świadomy jest swoich celów - o, z pewnością nie ziemskich, nie tych, jakie osiąga się przez krew. (Czy historia już czegoś nie nauczyła?) To żołnierze Ducha, wyzwalający jego królestwo i jednocześnie w chwale stający u bram Niebios (bardzo wyraźnie są tu obecne echa mesjanistycznej koncepcji Cieszkowskiego z jego przekonaniem, że oto ludzkość staje „u progu trzeciej i ostatniej epoki dziejów - epoki Ducha Sw.", w której dokona się „przeobrażenie moralne i religijne człowieka." 4. To ci wreszcie, którzy stając po stronie Dobra uczestniczą w jego pojedynku ze Złem i wpisują się jednocześnie w charakteryzującą mesjanistów manichejską wizję świata. Tak chciał widzieć legion poeta - nieco inne jednak było spojrzenie tych, którzy mieli stanowić o jego liczebności i kształcie.

Mickiewiczowskie pojmowanie ,legionu" podprowadza nas pod drugą z kolei, obecną w sztuce Wyspiańskiego, interpretację tegoż terminu. Praktyczny Słownik Biblijny (W-wa, 1994, s. 646) informuje: „W NT terminu tego nigdy nie używa się w sensie wojskowym, lecz wyłącznie na oznacznie wielkiej liczby: Mt 26,53 na oznaczenie wielkiej liczby aniołów, Mk 5,9.15 mnóstwa demonów". Pozostaniemy przy znaczeniu obecnym w Ewangelii Marka. Co jednak bardzo ciekawe i ważne - tekst dramatu nie przynosi słowa „legion" o takim właśnie, biblijnym, znaczeniu. Wyspiański wyraźnie oddziela owe dwa znaczenia: militarno-historyczne $\mathrm{i}$ to poparte tekstem Biblii, przenosząc ów legion demonów w postać głównego bohatera - Mickiewicza (nie zaznaczając tego jednak terminem „legion”). Można powiedzieć, że pomiędzy czasem historycznym - wydarzeniami tu i teraz a wielką historią chrześcijaństwa staje człowiek. Człowiek, który przecież $w$ historii tej dorasta, ale którego korzenie sięgają chrześcijaństwa - owej gleby formującej jednoznacznie pewien świat wartości.

Spróbujmy ująć i sproblematyzować przebieg biblijnej relacji, którą przynoszą nam ewangelie Marka (Mk 5,1-17) i Łukasza (Łk 8,26-39), a w której to Chrystus uzdrawia opętanego. Szczególną uwagę zwróćmy na postać chorego człowieka i jego „przesunięcie” względem osoby Jezusa.

1. Opętany przez złe duchy człowiek staje wobec Chrystusa. (relacja Opętany - Chrystus)

4 Stownik literatury polskiej XIX wieku, Wroclaw 1991, s. 538 (hasło: mesjanizm). 
2. Chory człowiek zostaje oczyszczony poprzez wypędzenie $z$ jego ciała złych duchów. (relacja Oczyszczony - złe duchy)

3. Chrystus nakazuje duchom nieczystym wejść w świnie (były Opętany poprzez swoją czystość staje nie wobec, ale za Chrystusem, włącza się w działanie Jego mocy). (relacja Chrystus były Opętany - świnie)

Główny bohater dramatu - Adam Mickiewicz - doskonale wpisuje się w ów schemat. Dostrzec można zachodzącą w nim ewolucję, która pozwala wyróżnić trzy etapy jego istnienia jako postaci w utworze Wyspiańskiego:

- Mickiewicz jako opętany,

- Mickiewicz jako oczyszczony,

- Mickiewicz jako Chrystus.

Czy główna postać dramatu to człowiek opętany?

„Opętanie jest to stan, w którym zły duch, wszedłszy w ciało człowieka, opanowuje wszystkie jego członki i organa, każe mu działać według swej szatańskiej woli i popycha go w momentach kryzysu do czynów, których opętany często nie pamięta." 5 Biblijny opętany - to ten, który ,już od dłuższego czasu nie nosił ubrania i nie mieszkał w domu lecz w grobach" (Łk 8,27). Mickiewicz zamieszkuje groby, bo jego idea - wskrzeszenia legionów - to idea umarła, która spopieliła się $\mathrm{w}$ czasie historii. Ale poeta w bardziej namacalny sposób uczestniczy w owej atmosferze śmierci - rozmowa z Krasińskim (sc. III) to dialog, podczas którego dokonuje się w Mickiewiczu, w jego postępowaniu, niezwykła przemiana. Musimy sobie uświadomić, że owa rozmowa ma miejsce w Kolosseum, w którym „bramy i szpalery architektury pokryte darnią mchów, chwastami, bluszczem; na gzemsach kołyszące, sczerniałe, wyschłe cyprysy" (sc. III, didaskalia), w ponurym krajobrazie cmentarza przeszłości, na którym czuć jeszcze teraz zapach krwi, rozszarpywanych przez wygłodniałe lwy, ciał chrześcijan.

„Rytuał rzymski wyróżnia trzy podstawowe cechy świadczące o opętaniu: mówienie nie znanymi pacjentowi językami lub rozumienie ludzi, którzy nimi mówią, odnajdywanie rzeczy ukrytych lub znajdujących się daleko, dysponowanie siłą przewyższającą normalną dla danego wieku czy budowy ciała." 6 Język, jakim posługuje się Mickiewicz, ani trochę nie przypomina tego właściwego komunikacji. Zwroty do wyimaginowanej postaci Sławy wypowiadane żarliwym tonem profety to rzeczywiście język inny - język mesjanistów:

O Sławo, o Duchu Sławy!

gdzie ognie twe, gdzie zjawiska

gdzie orszak Sprawników sprawy

5 J.-P. Roux, Jezus, Kraków 1995, s. 307.

6 J.w. 
kędy wielkie orężne igrzyska,

kędy legion twój zwycięzców krwawy?

o Sławo, o Sławo, Sławo!

(sc. III, ww. 85-90)

Sam poeta $w$ próbie uchwycenia owych cech mowy, jaką włada, dostrzega jej niewątpliwą odmienność od języka żywych:

Umarłych mówiłem mową (...)

(sc. III, w. 125)

Ale sposób mówienia to nie jedyna właściwość owego zagadkowego stanu romantycznego wojownika. Potrafi on widzieć więcej (Młoda Polska przecież niezwykle wysoko waloryzowała opętanego - przez jego nieuchwytną zdolność kontaktu z tym, co niedotykalne, niewidzialne, co poza racjonalnym doświadczeniem) - przechodzi tajemniczą granicę empirii, by inaczej spojrzeć na materię nieożywioną:

Kamienie drgnęły;

o, cicho, w kamieniach czucie;

krew zabiła w kamieniach i woła;

krew drgnęła i w głazie jęka (...)

(sc. III, ww. 94-97),

by wskrzesić zamkniętą w poetyckiej wyobraźni postać zmartwychwstałej Niepodległej:

O, widzisz ją białą, bladą;

idzie przez strzaskane kolumny; (...)

O, znam upiorne straszydła;

widzisz ją - Slowo się stało -

powolną, potężną, białą,

idzie $\operatorname{tam} \mathrm{z}$ rozwartych podwoi.

(sc. III, ww. 134-135, 141-144)

Wreszcie odnajduje $\mathrm{w}$ sobie siłę nieludzką, przekraczającą dalece jego kruchą fizyczność poety - czy jest to moc boska czy może szatański podszept?

(...) duchy zwolywam gromadą,

oto przyjdą i ręce pokładą

na czoło - czasy posiędę.

(sc. III, ww. 126-128)

Krasiński, najbliższy obserwator owych zmian w przyjacielu zgodny jest $\mathrm{z}$ naszą hipotezą - Mickiewicza dotknęło opętanie, a w ciele jego zamieszkał zły duch:

(...) dusza twoja obłąkana (...)

(sc. III, w. 106) 
Oddal się (...)

To Piekieł upiorne Moce.

(sc. III, w. 148, 150)

Sam poeta stając przed męczennicą - „świętą" Matką Makryną Mieczysławską (o obłudzie której Wyspiański nic jeszcze nie wiedział) - próbuje definiować swój stan przeczuwając to, co najgorsze $\mathrm{i}$ w podświadomości kryjąc przeogromne pragnienie oczyszczenia:

Koło mnie przepaście odmętu, straszliwie piekielne upiory, nie podołam przemóc wstrętu (...)

Łaski, jestem duszą chory.

(sc. IV, ww. 56-58, 70)

Ale w tym, zdawać by się mogło, udręczonym człowieku odzywa się głos buntu, głos poszukujący winnego poza samym sobą -

(...) martwota mię w Noc wiedzie ciemną;

sklep mię mroźnych marmurów pochłania;

miasto duchów zmartwychwstania

lęku widziadło mnie goni,

modlitwa moja daremną,

Boga nade wszystko winuję.

(sc. IV, ww. 90-95)

To ostatnie zdanie zostanie potwórzone raz jeszcze. Czy przypominamy sobie ową zuchwałą odwagę biblijnego opętania? „Gdy ujrzał Jezusa, z krzykiem upadł przed Nim i zawołał: „Czego chcesz ode mnie, Jezusie, Synu Boga Najwyższego? Błagam Cię, nie dręcz mnie" (Łk 8,28). Mickiewiczowi także przyjdzie upaść przed majestatem Chrystusa, ale w pełnej skrusze. Tu już powoli wyrastać zaczyna ów moment, kiedy poeta stając w pokorze przed księdzem Jełowickim, następnie - papieżem Piusem IX, uobecni element biblijnej opowieści, w którym opętany staje wobec Pana. Owym pierwszym Chrystusowym Namiestnikiem jest ksiądz, do którego słowa wyrażające pragnienie głębokiego pojednania kieruje Mickiewicz:

(...) przychodzę tu w Imię Boże

po Słowa bożego pociechy;

chcę tu z siebie zmyć oszczerstwo,

chcę brudy ostawić i grzechy (...)

Chcę spowiedzi.

Spojrzy na mnie jak Duch się mój biedzi.

(sc. V, ww. 90-93; sc. IV, ww. 94-95)

Tym, który uzdrawia Opętanego - napełniając go odwagą przyszłego wodza, błogosławiąc na drogę jest - współczesny Piotr: 
Już serce $\mathrm{w}$ Tobie nie chore, bole i klęski w pierś biorę;

bądź jako hetman zwycięski (...)

Błogosławię, błogosławię (...)

(sc. VI, ww. 346-348, 358)

Mickiewicz jako oczyszczony - takim postrzegają swojego twórcę ożywione postacie bohaterów wpisane przecież w świat pogański (litewskie boginki, świtezianki, guślarze, znachory, wiedźmy - sc. VIII, didaskalia). Pojednany $z$ Bogiem, wolny od złych duchów, spragniony krzyża - czy przez cierpienie pragnie się włączyć w mękę i śmierć Chrystusa?

Zapatrzony w Boga, który kona, W krzyżowego jedno patrzy Boga, patrzy w krzyż.

(sc. VIII, ww. 196-198)

Bycie w wielkiej harmonii $\mathrm{z}$ Chrystusem - to znak do rozpoczęcia działań złego, który opuściwszy wnętrze swej ofiary, teraz atakuje ją z zewnątrz. Pojawiający się w scenie IX Demos - to przecież kusiciel, który znając wielkie marzenie poety o niosących Polsce wolność legionach, potężnych swoją siłą, ten element właśnie uczyni kartą przetargową swoich zabiegów. Konflikt racji między ludem żądającym krwi a jego przewodnikiem, duchowym przewodnikiem, który staje w obronie świętości, stara się wykorzystać Demos:

Ukórz się przede mną w duchu, a oddam legiony w. posłuchu.

(sc. IX, ww. 170-171)

Mickiewicz jednak pozostaje stanowczy i nieprzejednany rozpoznając w natrętnej postaci - szatana:

Wybrałem duszy spokoje

przekląłem królestwo ziemi,

gardzę służbami twojemi (...)

Poznaję szatańskie państwo (...)

(sc. IX, 166-168, 175)

Niezwykle wyraźnie postać poety nabiera już Chrystusowych cech poprzez uczestnictwo w sytuacji kuszenia, a także - swoją samotniczą walkę ze złem.

Mickiewicz jako Chrystus - to trzeci etap jego drogi, w której tak bliski przecież postaci biblijnego opętanego, włącza się w wielkie dzieło Jezusa pozostawiając poza sobą to, co złe. Często, a może zawsze, ceną tego wyboru jest ziemskie cierpienie otwierające jednak bramę do innego świata. Poeta wraz z dwunastoma uczniami - legionistami (,Do wymarszu z Rzymu Mickiewicz zebrał (...) zaledwie dwunastu ochotników, głównie studentów z Akademii Sztuk Pięknych. 
Jeden był tam tylko doświadczony wojskowy (...)" 7 opuszcza Romę drogą niezwykle bogatą w symboliczny sens: drogą wśród ,grobowców, sarkofagów, stel rzeźbionych cmentarnych, cyprysów jako strażników grobów, wierzb płaczących" (sc. XI, didaskalia). Taka będzie ta droga dochodzenia do Nowego Jeruzalem, do nowego miasta - jak określają cel swojej wędrówki legioniści. Ten cel to przecież w perspektywie historycznej owa wymarzona Niepodległa stająca się w egzystencjalnie zabarwionym spojrzeniu Niebieskim Jeruzalem, do którego chee zmierzać każdy chrześcijanin.

Moment Ostatniej Wieczerzy kryjący w sobie bogactwo biblijnych odwołań:

\section{Mistrzu, to niebieskie uroki, przemieniłeś wodę ze zdroju; \\ Oto pijem spragnieni pokoju:}

Smak wody, żywego smaku wina

(sc. XI, ww. 54-57),

bo przecież i dokonany przez Chrystusa cud w Kanie Galilejskiej i misterium przemienienia $\mathrm{w}$ wigilię śmierci, rozsnuwa wizję przyszłego cierpienia i jednocześnie radości.

Oddalenie się od spożywających posiłek i smutek Mickiewicza, powodem którego przeczuwana zdrada - splata ową wizję zawartą w utworze z obecnością Chrystusa w Ogrodzie Oliwnym, gdzie przeczuciu okrutnego bólu towarzyszyła samotność człowieka.

Poeta znajdując głęboką ufność i dziecięce oddanie u legionistów, a nade wszystko u tego, „który podobny Janowi Swiętemu”, łumaczy sens przyszłych wypadków, daleko przekraczających jednostkowe życie człowieka, których oni niestety nie pojmą zatrzymując spojrzenie na własnej osobie $i$ własnym tu i teraz istnieniu.

Wy, którzyście się pierwsi pośpieli, zaprawdę bądźcie weseli, wiarą bądźcie weseli, wiarą bądźcie warowni: ojczyznę będziecie mieli, lecz zginiecie jako ptacy wędrowni.

Zaprzysięgnijcie wytrwanie (...)

Jeruzalem żywa wstanie! (...)

I pamięć o was zaginie.

Jeno życie wasze w czynie.

(sc. XI, ww. 105-110, 144, 146-147)

Dramatyczne wydarzenia na Łodzi, w której żagiel białej chorągwi z wizerunkiem Chrystusowej twarzy (przy maszcie - Mickiewicz;

7 Cyt. za: J. N ow a k ow s ki, tamże, s. XXXIV. 
obraz jak dalece przypominający malowidło wazowe $\mathrm{z} V$ w. przed Chr., na której wizerunek Odyseusza przywiązanego do masztu łodzi Ojcowie Kościoła wykładali jako postać Chrystusa na krzyżu.8) dmucha śmierć wyłaniająca się ze wzburzonych wód kłębiących się ciałami ,żrejącymi się wzajem, szarpiącymi, mordującymi” (sc. XII, didaskalia), są spełnianiem się zapowiedzi poety. Buntujący się, przykuci łańcuchami do łodzi legioniści, nie rozumieją dokonującego się odrodzenia przez śmierć, podobnie przecież jak uczniowie Chrystusa nie rozumieją słów o powstaniu z martwych (i będą mieli trudności z uwierzeniem nawet dotykając zmartwychwstałego Pana). Mickiewicz jednak widząc w tej wielkiej ofierze krwi budzącą się wolność Polski, poprzez apokaliptyczne wody i płomienie ognia, wykrzykuje:

Umarłe! Smierć was odrodzi! (...)

Zmartwychwstaniecie - mlodzi!

Czy jego głos wciąż możemy utożsamiać z głosem Chrystusa przemawiającego do swoich uczniów i do każdego chrześcijanina?

Mickiewicz - Chrystus, były Opętany kroczący drogą Jezusa i głoszący Jego naukę - ostatnie słowa dramatu stają się równocześnie zamknięciem trzeciego etapu owych paraleli: Mickiewicz - Opętany, Mickiewicz - Oczyszczony, Mickiewicz - Chrystus, które pozwalając spinać Historię i Biblię wspisując postać polskiego poety romantycznego $\mathrm{w}$ opowieści o uzdrowieniu opętanego.

Kraków

IZABELA BARTKOWICZ

\section{SPRA WOZDANIAI WIADOMOSCI}

\section{Ks. Tadeusz Matras}

\section{SESJA POLSKICH BIBLISTÓW (CZĘSTOCHOWA 1994)}

15-16 września 1994 r. Sekcja Biblistów Polskich obradowała w gmachu Wyższego Seminarium Duchownego Archidiecezji Częstochowskiej w Częstochowie. Swoje obrady rozpoczęła Mszą św. koncelebrowaną w ka-

8 Por. M. Lurker, Przestanie symboli $w$ mitach, kulturach $i$ religiach, Kraków 1994, s. 302-303. 